\title{
Comparative Study In The Bibiani, Bolgatanga, Dunkwa And Tarkwa Mining Districts Of The Minerals Commission Of Ghana
}

\author{
George Lord Opoku-Antwi, Sunyani Polytechni, Ghana \\ Kwaku Amofah, Sunyani Polytechnic, Ghana \\ Kofi Nyamaah-Koffuor, Sunyani Polytechnic, Ghana
}

\begin{abstract}
This paper aims to provide a comparative study on the Ghanaian small-scale gold mining industry in the Bibiani, Bolgatanga, Dunkwa and Tarkwa Districts of the Minerals Commission of Ghana. Variations in production, employment, number of licensed operators/concessions were the main focus of the paper. A two-way analysis of variance (ANOVA) was used to 1) test for the means of equality for the period 2005 to 2008 in order to find the column effect and 2) test for the means of equality between the mining districts (distance) to help find the column effect. It then looks at the structure-conduct-performance to explain the differences in the mining districts. The paper concludes that even though the small-scale mining sector in Ghana is beset with a number of challenges, it should be recognised as a significant generator of rural livelihoods that has the potential to alleviate poverty and be a tool for sustainable development. Assistance based on an integrated approach that considers operational, financial, organisational, social, economic, legal, technical and environmental issues should be offered to enhance small-scale gold mining operations in Ghana.
\end{abstract}

Keywords: Small-Scale Gold Mining; Production; Employment; Concession; Structure-Conduct-Performance

\section{INTRODUCTION}

$\mathrm{n}$ many parts of the world, artisanal, or small-scale mining (ASM) activities, are as important as largescale mining activities, particularly in terms of the number of people employed. In most developing countries, small-scale mining plays a crucial role in poverty alleviation and rural development. According to the International Labour Organization (1999), about 13 million people working directly in small mines throughout the world are mainly in developing countries.

In Ghana, the extraction and subsequent processing of gold mineral by the small-scale mining sub sector has been carried out for decades and provided thousands of Ghanaians with employment. This grass-root industry has also made important contributions to foreign-exchange earnings and is now recognized by the government of Ghana as one of the cornerstones of the extractive sector and the economy as a whole.

To make the small-scale mining sub-sector a more sustainable and efficient economic activity, in 1989 the Ghanaian government, the World Bank and Gesellschaft Technishe Zusannebarbeit (GTZ), a German NGO, undertook a number of initiatives to formalise and regularise resident small-scale mining operations (World Bank, 1995). In order to address these emerging developments, in recent times Ghanaian governments have established a number of institutional and legal framework to regularize small-scale gold mining operations in the country. Notably among the institutions that provide administrative and regulatory mechanisms for small-scale mining operations in Ghana, according to the World Bank (1993) and Jennings (1993), are the following: 
- $\quad$ The Ministry of Lands, Forestry and Mines oversees all aspects of the Ghanaian mineral sector and is the grantor of mineral and energy exploration and mining leases. Within the ministry is the Minerals Commission, which was established by the Minerals Commission Act of 1993 (Act 450). The Commission has responsibility for administering the Mining Act, recommending mineral policy, promoting mineral development, advising the government on mineral matters, and serving as a liaison between the government and industry (Minerals Commission, 2007).

- $\quad$ The Precious Minerals Marketing Corporation Law of 1989 (PNDCL 219), set up the Precious Minerals Marketing Corporation (PMMC) to promote the development of small-scale gold and diamond mining in Ghana and to purchase the output of such mining either directly or through licensed buyers. The Ghana Geological Survey Department conducts geologic studies and the Mines Department has authority in mine safety matters.

- $\quad$ All mine accidents and other safety problems are reported to the Ghana Chamber of Mines, which is the private association of operating mining companies. The Chamber also provides information on Ghana's mining laws to the public and negotiates with the mine labour unions on behalf of its member companies.

- $\quad$ The Environmental Protection Agency (EPA) provides protection of the environment through policy formulation and economic, scientific and technological interventions needed to mitigate any harmful impacts caused by development activities, including mineral exploration and processing (Hentschel, 2002).

The regulation of small-scale gold mining was set forth in the Small-Scale Gold Mining Law of 1989 (PNDCL 218) and the Minerals and Mining Act of 2006 (Act 703). Other legislations that regularize mining and mineral exploration in Ghana include the Minerals and Mining Law of 1986 (PNDCL153), as amended by the Minerals and Mining (Amendment) Act of 1994 (Act 475); the Investment Promotion Act of 1994 (Act 478 ); the Additional Profits Tax Law of 1985 (PNDCL122); the Minerals Commission Law of 1986 (PNDCL 154); the Minerals (Royalties) Regulations of 1987 (LI 1349); the Environmental Protection Agency Act of 1994 (Act 490 ), and the Environmental Assessment Regulations of 1999.

The Minerals Commission currently runs seven small-scale mining district offices/centres in the country to compile a register of all and prospective small-scale gold miners and to supervise and monitor their operations and activities. These centres, which are different from the conventional administrative district assemblies, are located at Tarkwa, Dunkwa, Bibiani, Bolgatanga, Asankrangwa, Assin Fosu, and Akim Oda (Minerals Commission, 2007).

This paper aims at providing a comparative study on the Ghanaian small-scale gold mining industry, especially in the Bibiani, Bolgatanga, Dunkwa, and Tarkwa mining districts of the Minerals Commission of Ghana, in terms of production, employment, and concession levels. Proximity, familiarity, and the high intensity of smallscale mining activities are the main motivational factors that accounted for the selection of these districts.

The first section of this paper focuses on the methodology. Next, the inter-district comparisons, with particular reference to production volume, employment levels, and the number of licensed operators/concessions, are analyzed. In addition, a two-way analysis of variance on production volume, employment level, and the number of licensed operators/concessions is carried out. The paper then looks at the structure-conduct-performance to explain the differences in the mining districts. The paper concludes and provides recommendations. Finally, a list of details of some important background reading is provided.

\section{METHODOLOGY}

Data for the paper were collected from 2005 to 2008 to undertake a comparative study on small-scale gold mining in the Bibiani, Bolgatanga, Dunkwa and Tarkwa mining districts of Ghana. Primary and secondary data were collected from the district centres/offices of the Minerals Commission of Ghana. In this paper, both qualitative and quantitative methods were employed. The qualitative method included the use of in-depth interviews with smallscale miners in selected mining communities. The quantitative part involved a questionnaire of 22 items(13 structured and 9 unstructured) which was administered to the officials of the Bibiani, Bolgatanga, Dunkwa, and Tarkwa small-scale mining districts of the Minerals Commission of Ghana. Secondary data were also obtained from journals, magazines, newspapers, textbooks and the internet. Again, annual reports and quarterly bulletins of the Ghana Minerals Commission, Precious Minerals Marketing Company, Bank of Ghana and Ghana Statistical Service were the other secondary sources consulted. 
Percentages and graphs were the key techniques of data analysis in this paper. Percentages were used to describe relationships between the study variables while graphs were used to present components of the variables. A two-way analysis of variance (ANOVA) was used as a statistical tool to test for statistical interdependence between the mining districts and across the years.

A map of Ghana showing the study area is provided in the Appendix.

\section{FINDINGS AND DISCUSSIONS}

\section{District Comparative Analysis}

This section concentrates on the analysis of differences in the districts in terms of production, employment, number of licensed operators/concessions.

\section{Production}

As presented in Table 1 and Figure 1, the volume of gold production in the four mining districts showed an increasing trend over the years, except the Bibiani mining district/area which recorded a decrease of $31.62 \%$ between 2007 and 2008. Relatively, the Tarkwa mining district/area recorded the highest of 54.35\% of total production in the study area, followed by Dunkwa, Bolgatanga, and Bibiani districts with 23.29\%, 13.66\%, and $8.70 \%$, respectively. Table 1 shows the production figures from 2005 to 2008 .

Table 1: Annual Gold Production (in Ounces)

\begin{tabular}{|l|c|c|c|c|c|c|c|}
\hline \multicolumn{1}{|c|}{ Year } & $\mathbf{2 0 0 5}$ & $\mathbf{2 0 0 6}$ & $\mathbf{2 0 0 7}$ & $\mathbf{2 0 0 8}$ & Total & Average & Percentage \\
\hline District & & & & & & & \\
\hline Bibiani & 332.17 & $1,102.53$ & $4,184.08$ & $2,610.15$ & $8,228.93$ & $2,057.23$ & $8.70 \%$ \\
\hline Bolgatanga & 472.38 & $1,073.07$ & $5,215.46$ & $6,156.82$ & $12,917.73$ & $3,229.43$ & $13.66 \%$ \\
\hline Dunkwa & $3,422.41$ & $3,956.75$ & $6,332.11$ & $8,317.63$ & $22,028.90$ & $5,507.23$ & $23.29 \%$ \\
\hline Tarkwa & $7,042.81$ & $5,031.42$ & $18,951.18$ & $20,369.38$ & $51,394.79$ & $12,848.70$ & $54.35 \%$ \\
\hline Total & $11,269.77$ & $11,163.77$ & $34,682.83$ & $37,453.98$ & $94,570.35$ & $23,642.59$ & $100.00 \%$ \\
\hline Average & $2,817.44$ & $2,790.94$ & $8,670.71$ & $9,363.50$ & & & \\
\hline
\end{tabular}

Source: Compiled from the Bolgatanga, Bibiani, Dunkwa and Tarkwa District Centres, Small-Scale Gold Mining Department, Minerals Commission of Ghana, August 2009

Note: These figures exclude production from illegal miners.

An interesting issue was the sharp rise, in real terms, in the Bolgatanga district where production volume rose by approximately 386.03\% between 2006 and 2007. In addition, in 2007, the Bibiani, Tarkwa and Dunkwa Districts also recorded significant increases of approximately $279.50 \%, 276.66 \%$ and $60.03 \%$, respectively, over 2006 production. With reference to the annual average production in the four districts, it was reported that production fell by $0.94 \%$ between 2005 and 2006 but rose sharply by $210.67 \%$ and $7.99 \%$ between 2006 and 2007 and 2007 and 2008, respectively. Figure 1 shows the volume of gold production from 2005 to 2008 graphically.

The introduction of mechanised mining methods, such as the use of the Chinese hammer mill (the chang fa machine); excavators; equipment such as generating plants, compressors, drilling machines, conveyors, and pumping machines, in 2007 by Chinese, Korean, Russian, and other foreign companies, in addition to mining consultancy services provided by mine support service companies, accounted for the significant increase in the volume of production between 2006 and 2007. Table 2 provides detailed data on the quarterly production volume in the mining districts. 


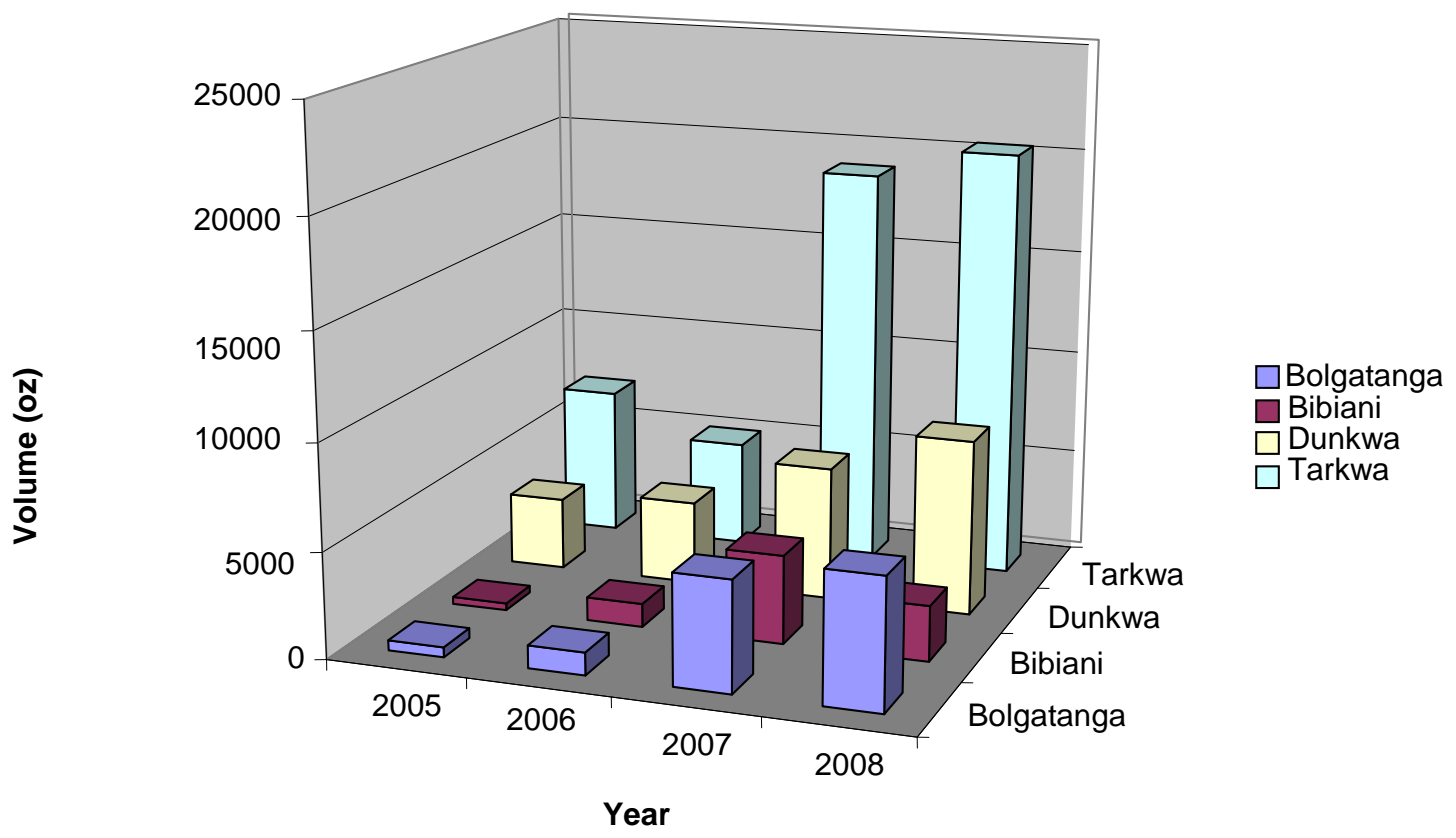

Figure 1: Gold Production (2005-2008)

Source: Compiled from the Bolgatanga, Bibiani, Dunkwa and Tarkwa District Centres, Small-Scale Gold Mining Department, Minerals Commission of Ghana, August, 2009

Table 2: Quarterly Production of Gold (2005-2008)

\begin{tabular}{|c|c|c|c|c|}
\hline Period $\quad$ District & Bibiani & Bolgatanga & Dunkwa & Tarkwa \\
\hline 2005: I & 78.36 & 115.04 & 637.66 & $1,531.14$ \\
\hline 2005: II & 54.87 & 93.62 & 492.51 & $1,028.73$ \\
\hline 2005: III & 110.41 & 139.01 & $1,329.45$ & $2,698.17$ \\
\hline \multirow[t]{2}{*}{ 2005: IV } & 88.53 & 124.71 & 962.79 & $1,784.77$ \\
\hline & 332.17 & 472.38 & $3,422.41$ & $7,042.81$ \\
\hline 2006: I & 202.76 & 198.38 & 711.35 & 842.27 \\
\hline 2006: II & 128.14 & 161.85 & 474.09 & 771.95 \\
\hline 2006: III & 511.70 & 403.11 & $1,721.18$ & $2,316.32$ \\
\hline \multirow[t]{2}{*}{ 2006: IV } & 259.91 & 309.73 & $1,050.13$ & $1,100.88$ \\
\hline & $1,102.53$ & 1,073.07 & $3,956.75$ & $5,031.42$ \\
\hline 2007: I & 617.43 & 831.07 & $1,326.67$ & $3,781.48$ \\
\hline 2007: II & 520.37 & 429.89 & 537.89 & 753.90 \\
\hline 2007: III & $2,057.25$ & $2,181.42$ & $2,473.03$ & $8,645.69$ \\
\hline \multirow[t]{2}{*}{ 2007: IV } & 989.03 & $1,773.08$ & $1,994.52$ & $5,770.11$ \\
\hline & $4,184.08$ & $5,215.46$ & $6,332.11$ & $18,951.18$ \\
\hline 2008: I & 473.19 & 762.37 & $2,140.84$ & $4,329.07$ \\
\hline 2008: II & 314.71 & $1,042.58$ & 581.36 & 838.61 \\
\hline 2008: III & $1,096.83$ & $2,615.64$ & $3,083.13$ & $8,998.87$ \\
\hline \multirow{2}{*}{ 2008: IV } & 725.42 & $1,745.23$ & $2,512.30$ & $6,202.83$ \\
\hline & $2,610.15$ & $6,156.82$ & $8,317.63$ & $20,369.38$ \\
\hline
\end{tabular}

Source: Compiled from the Bibiani, Bolgatanga, Dunkwa and Tarkwa District Centres, Small-Scale Gold Mining Department, Minerals Commission of Ghana, August, 2009

Note: Period I = January-March; Period II = April-June; Period III = July-September and Period IV = October - December 
It is interesting to report that during the period under review, quarterly production volume in all four of the mining districts followed a trend. Production volume remained robust with higher volumes of gold produced in the third quarter (July-September) of year compared to the first quarter (January-March) where lower volumes of production figures were recorded. The volume of gold production in the second and fourth quarters was, however, volatile as compared to the third quarter of each year where production reached its peak.

As mentioned earlier, a larger proportion of small-scale miners rely on traditional/manual methods of mining where simple equipment, such as cutlasses, axes, shovels, pick-axes, head pans, chisels, hammers, and sacks, among others, are used. The mineralized material is removed and transported to nearby rivers or streams because the traditional method depends solely on these water bodies as the main source of water for sluicing to recover the gold. The flow of water in the streams and rivers also depends on rain.

It could be observed that in Ghana, July-September is generally a period where the country experiences moderate rainfall. Mining activities becomes more brisk, less risky, and less expensive. Many people engage in mining operations and, thus, boost gold output from the small-scale mining sub-sector. During October-March, however, the country enters into the dry season where most of the bodies of water dry up. Many miners abandon their work and look for other manual jobs. Some pits get flooded during the second quarter (April-June) because this period is characterised with heavy rainfall, making small-scale mining activities more risky as more cave-ins of pits normally occur, which therefore affect production volume negatively. The quarterly production volumes are graphically presented in Figure 2.

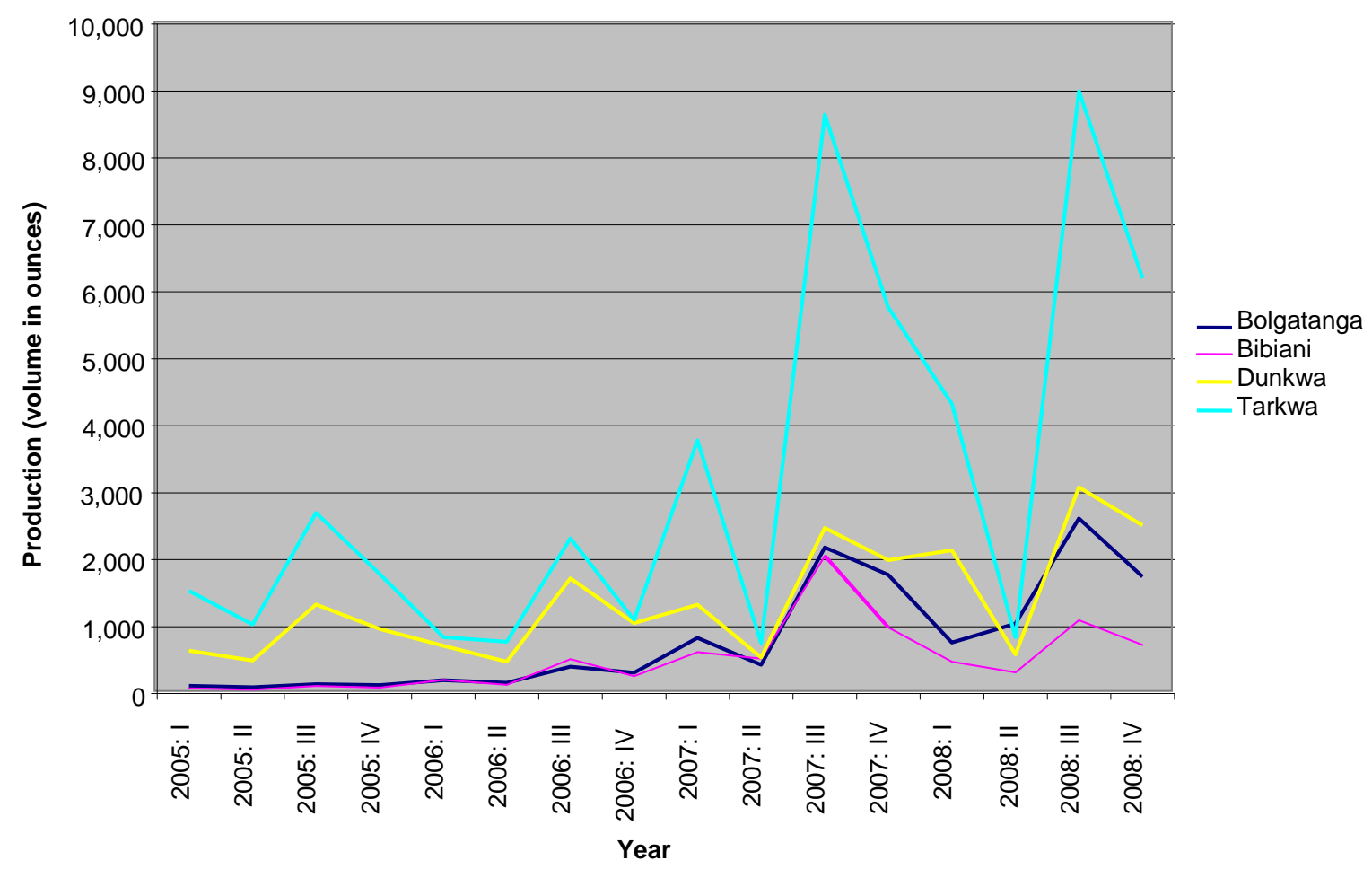

Figure 2: Quarterly Production (2005-2008)

Source: Compiled from the Bibiani, Bolgatanga, Dunkwa and Tarkwa District Centres, Small-Scale Gold Mining Department, Minerals Commission of Ghana, August, 2009

\section{Employment}

One significant contribution of small-scale mining is the employment opportunities it offers to thousands of people. Therefore, the study looked at the number of miners employed by licensed small-scale mining operators in 
the four districts. The details are reported in Table 3 and Figure 3. Apart from the Tarkwa mining district, which recorded a $49.87 \%$ drop in 2006, employment of labour by licensed operators kept on increasing in all the districts.

The Bolgatanga district accounted for the highest share (30.56\%) of the total employment level from 2005 to 2008 compared with the Bibiani, Dunkwa, and Tarkwa districts which registered 23.39\%, 27.14\%, and 18.91\%, respectively.

The highest and upward employment trend in the Bolgatanga district was attributed to the influx of smallscale miners from southern to northern Ghana for the purpose of avoiding rampant conflicts or conflicts of interest between small-scale miners and the larger-scale mining companies over ownership of mineral resources. Table 3 shows employment level by licensed operators from 2005 to 2008.

Table 3: Employment by Licensed Operators

\begin{tabular}{|l|c|c|c|c|c|c|c|}
\hline \multicolumn{1}{|c|}{ Year } & $\mathbf{2 0 0 5}$ & $\mathbf{2 0 0 6}$ & $\mathbf{2 0 0 7}$ & $\mathbf{2 0 0 8}$ & Total & Average & Percentage \\
\hline District & & & & & & & 2,456 \\
\hline Bibiani & 996 & 2,287 & 3,116 & 3,423 & 9,822 & $23.39 \%$ \\
\hline Bolgatanga & 1,419 & 2,163 & 4,335 & 4,915 & 12,832 & 3,208 & $30.56 \%$ \\
\hline Dunkwa & 1,741 & 2,755 & 3,043 & 3,859 & 11,398 & 2,850 & $27.14 \%$ \\
\hline Tarkwa & 2,372 & 1,189 & 1,579 & 2,801 & 7,941 & 1,985 & $18.91 \%$ \\
\hline Total & 6,528 & 8,394 & 12,073 & 14,998 & 41,993 & 10,498 & $100.00 \%$ \\
\hline Average & 1,632 & 2,099 & 3,018 & 3,750 & 10,498 & & \\
\hline Percentage & & $28.58 \%$ & $43.83 \%$ & $24.23 \%$ & & & \\
\hline
\end{tabular}

Source: Compiled from the Bolgatanga, Bibiani, Dunkwa and Tarkwa District Centres, Small-Scale Gold Mining Department, Minerals Commission of Ghana, August, 2009

Note: * The averages were converted to the nearest whole number.

Unlike production, the annual average number of people employed by licensed operators rose but fluctuated by $28.58 \%, 43.83 \%$, and $24.23 \%$ in the 2005-2006, 2006-2007 and 2007-2008 periods, respectively, although the inter district average number of people employed by licensed operators reached approximately 2,456, $3,208,2,850$, and 1,985 in the Bibiani, Bolgatanga, Dunkwa, and Tarkwa mining districts, respectively, as shown in Figure 3.

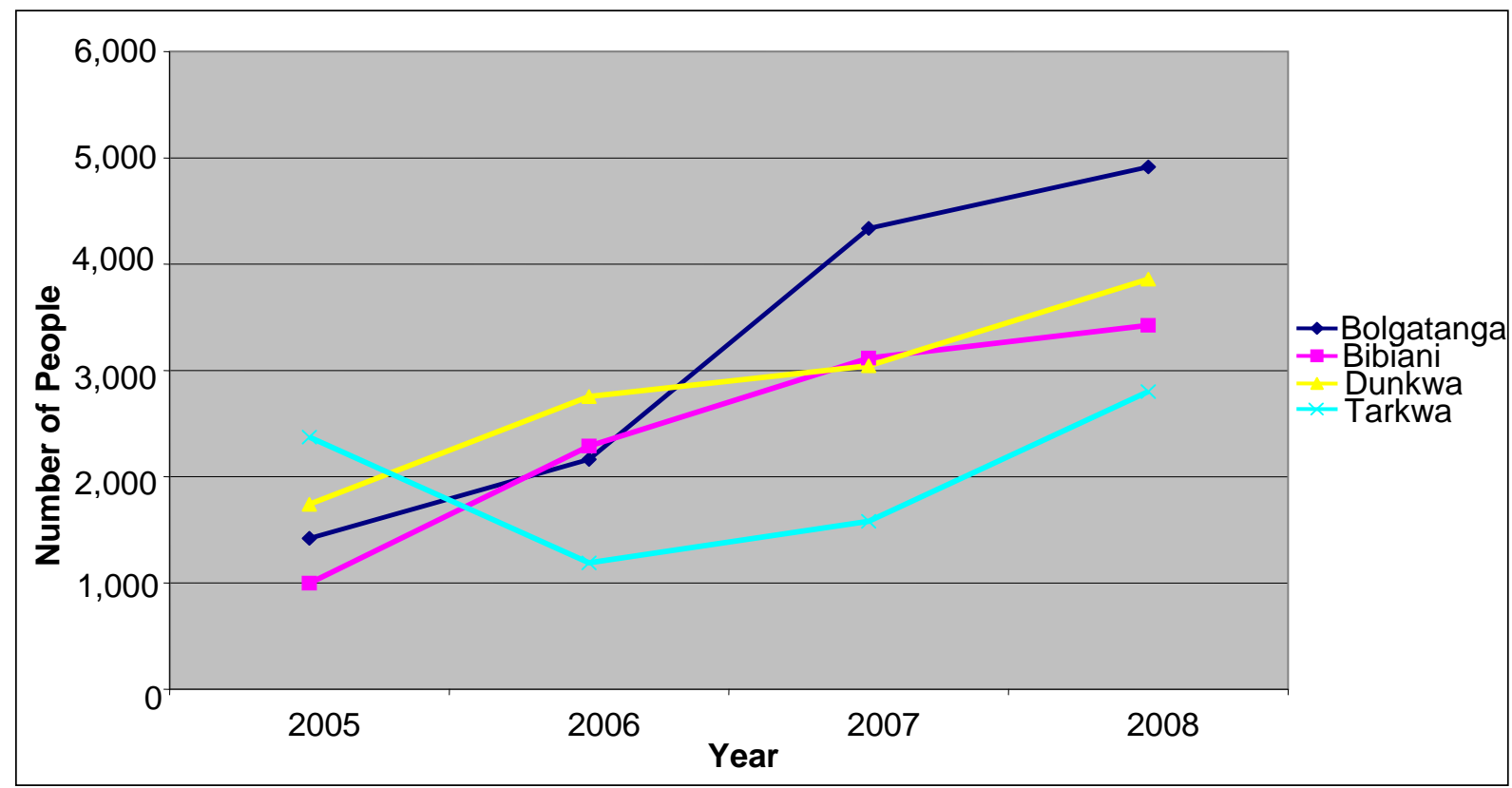

Figure 3: Employment by Licensed Operators (2005-2008)

Source: Compiled from the Bolgatanga, Bibiani, Dunkwa and Tarkwa District Centres, Small-Scale Gold Mining Department, Minerals Co0mmission of Ghana, August, 2009 


\section{Licensed Operators/Concessions}

Small-scale mining in Ghana is characterized by a large percentage of illegal or unlicensed operators. The study, however, reveals that people are gradually registering with the Minerals Commission and other stakeholder institutions to obtain mining license or mining concessions to operate legally. In relative terms, the Tarkwa district recorded the highest number of licensed operators/concessions, which stood at $40.89 \%$ in 2008, while the Bolgatanga district recorded the lowest number (12\%). Between the 2005 and 2006, 2006 and 2007, and 2007 and 2008 periods, annual growth in the numbers of licensed operators and concessions were $42.42 \%, 31.91 \%$, and $33.87 \%$, respectively. This suggests that the miners are gradually showing interest in investing in legal small-scale gold mining business. Table 4 and Figure 4 present the number of licensed operators/concessions in the four mining districts.

Table 4: Number of Licensed Operators/Concessions

\begin{tabular}{|l|c|c|c|c|c|c|c|}
\hline \multicolumn{1}{|c|}{ Year } & $\mathbf{2 0 0 5}$ & $\mathbf{2 0 0 6}$ & $\mathbf{2 0 0 7}$ & $\mathbf{2 0 0 8}$ & Total & Average* & Percentage \\
District & & & & & & & 11 \\
\hline Bibiani & 7 & 10 & 12 & 15 & 44 & $19.56 \%$ \\
\hline Bolgatanga & 4 & 6 & 7 & 10 & 27 & 7 & $12.00 \%$ \\
\hline Dunkwa & 9 & 13 & 18 & 22 & 62 & 16 & $27.56 \%$ \\
\hline Tarkwa & 13 & 18 & 25 & 36 & 92 & 23 & $40.89 \%$ \\
\hline Total & 33 & 47 & 62 & 83 & 225 & 56 & $100.00 \%$ \\
\hline Average* & 8. & 12 & 16 & 21 & & & \\
\hline & & $42.42 \%$ & $31.91 \%$ & $33.87 \%$ & & & \\
\hline
\end{tabular}

Source: Compiled from the Bolgatanga, Bibiani, Dunkwa and Tarkwa District Centres, Small-Scale Gold Mining Department, Minerals Commission of Ghana, August, 2009

Note: * The averages were converted to the nearest whole number.

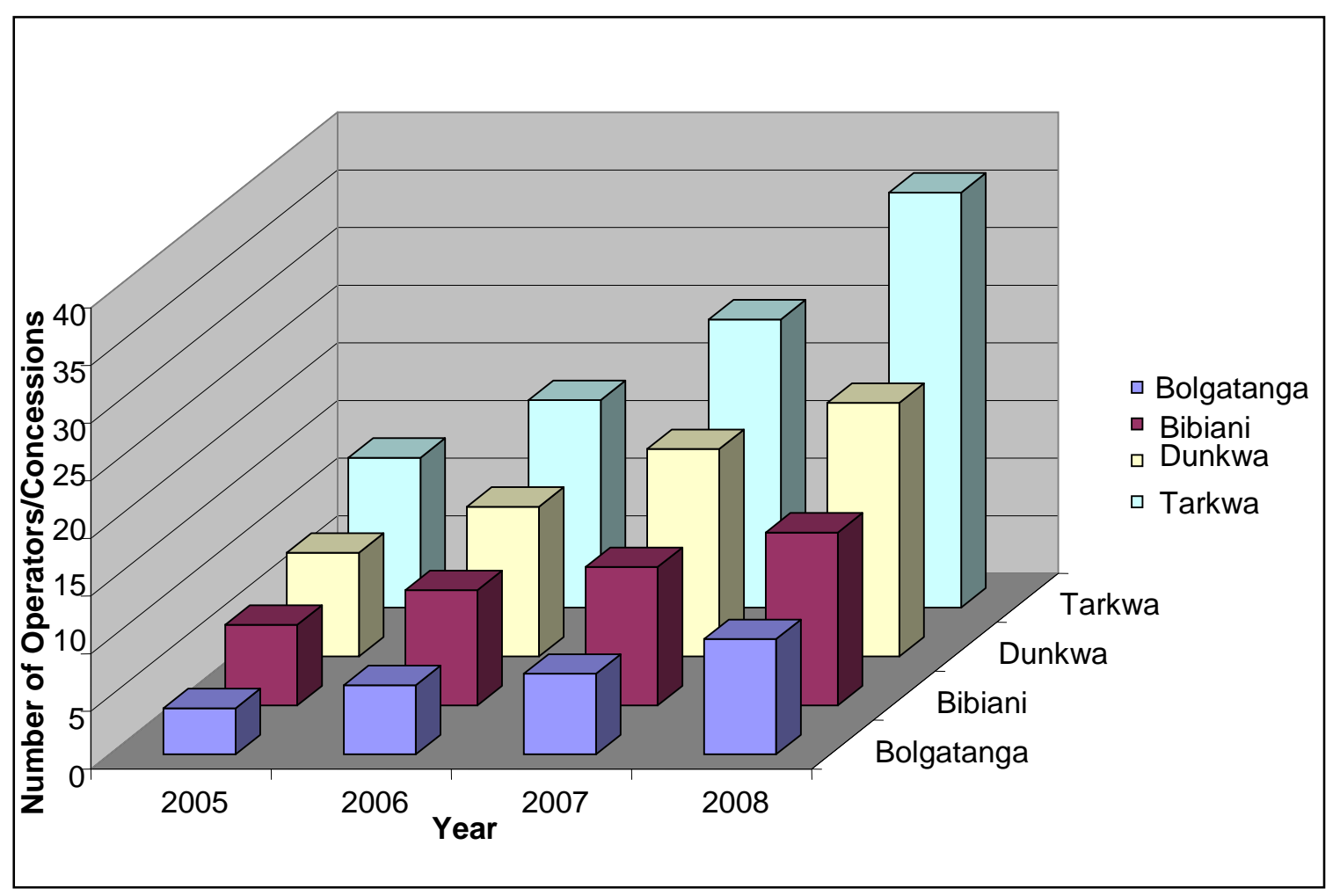

Figure 4: Number of Licensed Operators/Concessions (2005 - 2008)

Source: Compiled from the Bolgatanga, Bibiani, Dunkwa and Tarkwa District Centres, Small-Scale Gold Mining Department, Minerals Commission of Ghana, August, 2009 


\section{Analysis of Variance}

An analysis of variance (ANOVA), which is a statistical tool developed by Fisher (1970), was used. It analyzed data on production volume, employment levels by licensed operators, and the number of licensed operators/concessions in the mining districts, as reported in Tables 1,3, and 4. ANOVA was used to simultaneously test for the means of equality between the mining districts (location; i.e., row effect) and the means of equality across the years (from 2005 to 2008; i.e., column effect) (Koutsoyiannis, 2006). The paper made use of the Predictive Analytics Software (PASW), version 16 - formerly Statistical Package for Social Sciences (SPSS) - for the analysis and variances $(F$ statistic and critical $F$ ) were compared at 5\% degree of freedom.

\section{Hypotheses Testing}

The following hypotheses of equality were tested:

Hypothesis I: Hypothesis testing of equality of production volume (output) between the four districts.

The means of production volume between the four districts $\left(\mu_{1}, \mu_{2}, \mu_{3}\right.$ and $\left.\mu_{4}\right)$ are equal.

$\mathbf{H}_{0}: \mu_{1}=\mu_{2}=\mu_{3}=\mu_{4}$

$\mathbf{H}_{1}: \operatorname{Not} \mathrm{H}_{0}$

Hypothesis II: Hypothesis testing of equality of production volume (output) across the four years.

The means of production volume across the four years $\left(\mu_{1}, \mu_{2}, \mu_{3}\right.$ and $\left.\mu_{4}\right)$ are equal.

$\mathbf{H}_{0}: \mu_{1}=\mu_{2}=\mu_{3}=\mu_{4}$

$\mathbf{H}_{1}$ : Not $\mathrm{H}_{0}$

Hypothesis III: Hypothesis testing of equality of employment levels between the four districts.

The means of employment levels between the four districts $\left(\mu_{1}, \mu_{2}, \mu_{3}\right.$ and $\left.\mu_{4}\right)$ are equal.

$\mathbf{H}_{0}: \mu_{1}=\mu_{2}=\mu_{3}=\mu_{4}$

$\mathbf{H}_{1}: \operatorname{Not} \mathrm{H}_{0}$

Hypothesis IV: Hypothesis testing of equality of employment levels across the four years.

The means of employment levels across the four years $\left(\mu_{1}, \mu_{2}, \mu_{3}\right.$ and $\left.\mu_{4}\right)$ are equal, thus

$\mathbf{H}_{0}: \mu_{1}=\mu_{2}=\mu_{3}=\mu_{4}$

$\mathbf{H}_{1}:$ Not $\mathrm{H}_{0}$

Hypothesis V: Hypothesis testing of equality of the number of licensed operators between the four districts.

The means in the number of licensed operators between the four districts $\left(\mu_{1}, \mu_{2}, \mu_{3}\right.$ and $\left.\mu_{4}\right)$ are all the same.

$\mathbf{H}_{0}: \mu_{1}=\mu_{2}=\mu_{3}=\mu_{4}$

$\mathbf{H}_{1}: \operatorname{Not} \mathrm{H}_{0}$ 
Hypothesis VI: Hypothesis testing of equality of the number of licensed operators across the four years.

The means in the number of licensed operators across the four years $\left(\mu_{1}, \mu_{2}, \mu_{3}\right.$ and $\left.\mu_{4}\right)$ are all the same.

$\mathbf{H}_{0}: \mu_{1}=\mu_{2}=\mu_{3}=\mu_{4}$

$\mathbf{H}_{1}: \operatorname{Not} \mathrm{H}_{0}$

The results of the two-way ANOVA are reported in Tables 5, 6, and 7.

\section{Results and Analysis of the Inherent Hypothesis}

Three categories of hypotheses on production volumes, employment levels, and number of licensed operators/concessions were analysed.

\section{Production - Hypotheses I \& II}

In Table 5, the observed variance ratio (or computed $F$ ) $\mathrm{F}^{*}$ is 10.284 while the critical $F$ at $0.05 \%$ level of significance is 3.862. Since $\mathrm{F}^{*}>F$, we rejected the null hypothesis in Hypothesis I and accepted the alternative hypothesis that there is a significant difference between the means of the production volume across the districts. In the same way, since the computed $F\left(\mathrm{~F}^{*}\right)$ of 5.679 exceeds the critical $F$ value of 3.862, our suggestion is to reject the null hypothesis in Hypothesis II and accept the alternative hypothesis that the means of production volumes across the years are not equal.

Table 5: Production Results - Two-Way/Factor ANOVA

\begin{tabular}{|l|c|c|c|c|c|c|}
\hline Source of Variation & SS & df & MS & F* & P-value & F crit \\
\hline Rows (Mining Districts) & 281348034.2 & 3 & 93782678 & 10.28473 & 0.002886 & 3.862548 \\
\hline Columns (Years 2005-2008) & 155362254.1 & 3 & 51787418 & 5.679294 & 0.018373 & 3.862548 \\
\hline Error & 82067734.92 & 9 & 9118637 & & & \\
\hline Total & $\mathbf{5 1 8 7 7 8 0 2 3 . 2}$ & $\mathbf{1 5}$ & & & & \\
\hline
\end{tabular}

Source: Author's Estimations, October 2009

The rejection of the null hypothesis suggests that the difference between the means of the production volume between the mining districts is statistically significant and so are the means of the production volume across the years. This paper therefore proposes that both location (Bibiani, Bolgatanga, Dunkwa, and Tarkwa mining districts) and time (years 2005 to 2008) matter much as far as production is concerned.

Employment - Hypotheses III \& IV

In Hypothesis III, the paper cannot reject the null hypothesis, but accepts it because the $F$ statistic $\left(\mathrm{F}^{*}\right)$ of 1.917 was much less than the critical value of $F$, which was 3.862 at $0.05 \%$ level of significance, as shown in Table 6. Thus, the differences between the means of employment levels between the districts $\left(\mu_{1}, \mu_{2}\right.$ and $\left.\mu_{3}\right)$ are really equal and have no significant difference. However, we rejected the null hypothesis in Hypothesis IV and accepted that there is significant difference between the means of employment levels over the years. The reason was that the observed variance ratio, or $F$ statistic of 6.197, was greater than the critical $F$ value of 3.862 .

This implies that the means of equality of employment levels between the mining districts are not statistically significant while that of employment levels across the years are statistically significant. The paper therefore suggests that location (Bibiani, Bolgatanga, Dunkwa and, Tarkwa mining districts) does not matter much, but time (from 2005 to 2008) does matter much as far as employment levels are concerned. 
Table 6: Employment Results - Two-Way/Factor ANOVA

\begin{tabular}{|l|c|c|c|c|c|c|}
\hline Source of Variation & SS & df & MS & F* & P-value & F crit \\
\hline Rows (Mining Districts) & 3318313 & 3 & 1106104.23 & 1.917173347 & 0.197347 & 3.862548 \\
\hline Columns (Years 2005-2008) & 10726439 & 3 & 3575479.56 & 6.197258757 & 0.014312 & 3.862548 \\
\hline Error & 5192508 & 9 & 576945.34 & & & \\
\hline Total & $\mathbf{1 9 2 3 7 2 5 9}$ & $\mathbf{1 5}$ & & & & \\
\hline
\end{tabular}

Source: Author's Estimations, October 2009

\section{Licensed Operators/Concessions - Hypotheses V \& VI}

It could be observed from Table 7 that the $F$ statistic $\left(\mathrm{F}^{*}\right)$ is 16.697 while the critical $F$ value was 3.862 . We rejected the null hypothesis in Hypothesis $\mathrm{V}$ and accepted the alternative hypothesis that there is a significant difference between the means of the number of licensed operators/concessions between the mining districts $\left(\mathrm{F}^{*}>\right.$ $F$ ). Similarly, in Hypothesis VI, since the computed $F\left(\mathrm{~F}^{*}\right)$ of 9.908 exceeds the critical $F$ value of 3.862 , our conclusion is to reject the null hypothesis and accept the alternative hypothesis that the means of the number of licensed operators/concessions across the years are not equal.

Table 7: Licensed Operators/Concessions Results - Two-Way/Factor ANOVA

\begin{tabular}{|l|c|c|c|c|c|c|}
\hline Source of Variation & SS & df & MS & F* & P-value & F crit \\
\hline Rows (Mining Districts) & 579.1875 & 3 & 193.0625 & 16.6972973 & 0.000508 & 3.862548 \\
\hline Columns (Years 2005-2008) & 343.6875 & 3 & 114.5625 & 9.908108108 & 0.003274 & 3.862548 \\
\hline Error & 104.0625 & 9 & 11.5625 & & & \\
\hline Total & $\mathbf{1 0 2 6 . 9 3 8}$ & $\mathbf{1 5}$ & & & & \\
\hline
\end{tabular}

Source: Author's Estimations, October 2009

This indicates that the means of equality of the number of licensed operators/concessions between the mining districts are statistically significant and so are the means of the number of licensed operators/concessions across the years. The paper therefore suggests that, mutually, location (Bibiani, Bolgatanga, Dunkwa, and Tarkwa mining districts) and time (from 2005 to 2008) matter much as far as the numbers of licensed operators/concessions are concerned.

\section{Analysis of the Structure-Conduct-Performance (SCP)}

It could be emphasized that the differences in production volumes, employment levels, and number of operators in the four mining districts were expected. What is most interesting to the study is what explains the magnitude of the differences in the mining districts. Some factors, or issues of the SCP approach, which was first proposed by Mason (1939) and later modified by Bain (1956), were used to explain the magnitude of the differences in the mining districts.

Analysis of Structure

Under this, two key factors or issues - mainly managerial structures and ownership - were analysed.

\section{Managerial Structures}

When a new employee joins an organisation, one of the first things they learn is the company's management structure. Managerial structures, according to Hill (2007), include the understanding of the working relationships of employees with their manager, subordinates, and peer group. As mentioned earlier, two categories of small-scale mining operators exist in Ghana - licensed operators who are very few and illegal operators who form the majority.

Generally, all illegal small-scale mining operators, and most of the licensed operators in the Bibiani, Bolgatanga, Dunkwa and, Tarkwa mining districts, operate a simple, informal, or organic, management structure. 
The leader of each mining group (gang) defines the tasks, communicates the strategic goals, and uses his or her authority to influence the other miners or workers, such as talii boys and girls, karl men and women (for the meaning of talii boys and girls, karl men and women, see the notes under Table 8). Unlike the large-scale mining companies, the organic management structure is prevalent in most small-scale mining operations in Ghana and is characterized by flexible task definition, lateral communication, low degrees of formalization, expertise-based influence, decentralized control, and low degree of coordination.

The reason that accounts for the simple, informal, or organic management structures is the fact that the environment in which most small-scale mining organisations operate is highly uncertain and unstable (Hill, 2007). Hardly do we see small-scale mining operators using a balanced score card to measure both the organisation and individual performance.

There are insignificant numbers of small-scale mining operators with a formalized organisational structure that is hierarchical in nature, reflecting clearly-defined lines of authority and responsibility based on management theory. Hardly did we obtain documented records specifying the key components that underpin the management structure, such as task definition, communication style, influencing techniques, centralization, coordination, and formalization in small-scale mining operations in the study areas.

\section{Ownership}

A small-scale mine may be owned by a person, group of persons, or cooperative societies who are granted a license or permit to win, mine, and produce minerals by any effective and efficient method and is required to observe good mining practices, health and safety rules, and pay due regard to the protection of the environment during mining operations. In addition, a licence for small-scale gold mining operation may be granted to persons who are citizens of Ghana and have attained the age of 18 years (Small-scale Gold Mining Law of 1989) (PNDC Law 218).

It must be emphasized that there were no differences as far as ownership of mining concessions or operations in the four mining districts are concerned. In each of the districts, there were a few legal or licensed mining concessions or operations that are owned by a person (sole proprietorship), group of persons (partnership), or cooperative societies. However, most of the small-scale mining operations in the Bibiani, Bolgatanga, Dunkwa, and Tarkwa mining districts are done illegally and the miners neither observe good mining practices, health and safety rules, nor pay due regard to the protection of the environment during mining operations.

\section{Analysis of Conduct}

In analyzing conduct, the choice of technology was used.

\section{Choice of Technology}

Technology choice has important implications for growth and productivity in the small-scale mining subsector because the growth and productivity in the sub-sector depends on the ability of the miners to identify, select, and use the most suitable or appropriate technology (Ngahu, 1992). According to Ngahu (1992), the tools and equipment used and access to credit are among the key factors influencing the choice of technology in the smallscale enterprises.

Small-scale miners in the Tarkwa and Dunkwa mining districts use relatively higher technology because they are exposed to the services of mining servicing companies from China, Korea, Russia, and other foreign countries as compared to their counterparts in the Bibiani and Bolgatanga mining districts. This is as a result of the presence of large numbers of large-scale mining companies localized in the Tarkwa and Dunkwa mining districts.

The use or choice of modern equipment, such as hammer mills, especially the Chinese hammer mills (called the chang fa machines); excavators; generators; moist mechanisms; compressors; drilling machines; pumps; and disc mills; and technical advice in small-scale mining, is prevalent and therefore accounted for the differences in production levels and number of licensed operators/concessions in the Tarkwa and Dunkwa mining districts. 
In addition, lack of access to credit affects technology choice by limiting the number of alternatives that can be considered. Most private individuals (mining sponsors) prefer financing small-scale mining operations in the Tarkwa and Dunkwa mining districts to the Bibiani and Bolgatanga mining districts. They explain that investing in the Tarkwa and Dunkwa mining districts brings quick and higher returns and are less risky. Many small-scale miners in the Bolgatanga and Bibiani mining districts, on the other hand, use simple tools, such as shovels, pick axes, head pans, cutlasses, axes, and sacks, which therefore affects output and efficiency.

It must be noted that the differences in the relatively higher levels of production and employment levels in the Tarkwa and Dunkwa mining districts on one hand, and relatively lower levels of production and employment levels in the Bibiani and Bolgatanga mining districts on the other hand, did not consider the negative impacts on the physical environment. It was observed that the more the miners use mechanized methods in production, the more the environment is destroyed.

\section{Analysis of Performance}

Profitability was also used to explain performance.

\section{Profitability}

One of the major variables that explain the magnitude of differences in the mining districts is profitability. The miners, particularly the concessionaires (site owners), explain that profitability in small-scale mining depends on the revenue and operating cost. Revenue accrued from small-scale mining operations also depends on the price of gold, carat (the quality of gold), and quantity of gold in the area, while the operating cost includes cost of wages, cost of hiring machinery or equipment, feeding cost, transportation cost or nearness of the location of the mine or the mining site to a source of water body, and fees paid to the community - traditional rulers, unit committees, and landlords.

Table 8 provides details of the differences in the districts in terms of cost of wages paid to workers and gold price, as well as revenue, operating cost, and profit for operators using the traditional or mechanized methods. It must be emphasized that two kinds of revenue, operating costs, and profitability exist in all the mining districts one for operators using the traditional method of mining and the other for those using the mechanized method. In terms of wage payments, operators in the Bibiani mining district, for example, paid between $\mathrm{GH} \not 12.00$ and 15.00 to talii boys, GH $\phi 15.00$ to talii girls, and GH $\phi 20.00$ to 25.00 to karl men, while talii boys, talii girls, and karl men are paid $\mathrm{GH} \phi 20.00$, GH $\phi 15.00$, and $\mathrm{GH} \phi 25.00$, respectively, in the Tarkwa and Dunkwa mining districts.

The average operating cost per week for operators using the traditional method in the Bibiani, Bolgatanga, Dunkwa, and Tarkwa districts were $\mathrm{GH} \not 1,050.00, \mathrm{GH} \not 1,050.00, \mathrm{GH} \not 1,250.00$, and $\mathrm{GH} \not 1,500.00$, respectively, whereas those using the mechanized method in the Bibiani, Bolgatanga, Dunkwa, and Tarkwa districts were $\mathrm{GH} \phi 2,700.00, \mathrm{GH} \notin 3,100.00, \mathrm{GH} \notin 3,750.00$, and $\mathrm{GH} \phi 4,600.00$, respectively.

Finally, with respect to profit, operators using traditional methods earn a weekly profit of GH $₫ 350.00$, GH $\phi 300.00$, GH $₫ 350.00$, and GH $\phi 400.00$ in the Bibiani, Bolgatanga, Dunkwa, and Tarkwa districts, respectively, whereas operators using the mechanized method earn GH $\phi 750.00$, GH $\phi 530.00, \mathrm{GH} \phi 790.00$, and $\mathrm{GH} \phi 820.00$ in the Bibiani, Bolgatanga, Dunkwa, and Tarkwa districts, respectively.

It could be observed that a very few legalized small-scale mining operators in the four mining districts prepare financial statements, such as profit and loss account and balance sheet, to ascertain their financial standing. However, very few legalized small-scale mining operators measure both organisation and individual performance in terms of efficiency and effectiveness by the use a balanced score card. 
Table 8: Profitability in the Mining Districts

\begin{tabular}{|c|c|c|c|c|}
\hline Issues & Bibiani & Bolgatanga & Dunkwa & Tarkwa \\
\hline $\begin{array}{l}\text { Cost of wages } \\
\text { per day }\end{array}$ & $\begin{array}{l}\mathrm{GH} \phi 12.00-15.00^{\mathrm{a}} \\
\mathrm{GH} \phi 15.00^{\mathrm{b}} \\
\mathrm{GH} \phi 20.00-25.00^{\mathrm{c}}\end{array}$ & $\begin{array}{l}\mathrm{GH} \phi 8.00-10.00^{\mathrm{a}} \\
\mathrm{GH} \phi 7.00-9.00^{\mathrm{b}} \\
\mathrm{GH} \phi 15.00-20.00^{\mathrm{c}}\end{array}$ & $\begin{array}{l}\mathrm{GH} \notin 20.00^{\mathrm{a}} \\
\mathrm{GH} \varnothing 15.00^{\mathrm{b}} \\
\mathrm{GH} \varnothing 25.00^{\mathrm{c}}\end{array}$ & $\begin{array}{l}\mathrm{GH} \varnothing 20.00^{\mathrm{a}} \\
\mathrm{GH} \not 15.00^{\mathrm{b}} \\
\mathrm{GH} \phi 25.00^{\mathrm{c}}\end{array}$ \\
\hline $\begin{array}{l}\text { Feeding** } \\
\text { Cost per day }\end{array}$ & $\mathrm{GH} \phi 12.50$ & $\mathrm{GH} \not 12.00$ & $\mathrm{GH} \not 12.50$ & $\mathrm{GH} \not 15.00$ \\
\hline $\begin{array}{l}\text { Type of } \\
\text { mining }\end{array}$ & $\begin{array}{l}\text { - Underground } \\
\text { (pit/ghetto) } \\
\text { - Surface/open pit } \\
\text { (dig \& wash) }\end{array}$ & $\begin{array}{l}\text { - Underground (pit/ghetto) } \\
\text { Surface/open pit } \\
\text { (dig \& wash) }\end{array}$ & $\begin{array}{l}\text { - Underground } \\
\text { (pit/ghetto) } \\
\text { - Surface/open pit } \\
\text { (dig \& wash) } \\
\text { - Dredging }\end{array}$ & \begin{tabular}{|l} 
- Underground \\
(pit/ghetto)
\end{tabular} \\
\hline $\begin{array}{l}\text { Gold Price } \\
\text { per pound (lb) }\end{array}$ & $\mathrm{GH} \phi 45.00-60.00$ & $\mathrm{GH} \phi 50.00-60.00$ & $\mathrm{GH} \phi 50.00-65.00$ & $\begin{array}{l}\mathrm{GH} \phi 50.00-65.00 \\
\text { for unrefined gold } \\
\text { - } \mathrm{GH} \phi 90.00-100.00 \\
\text { for refined gold }\end{array}$ \\
\hline $\begin{array}{l}\text { Cost of hiring } \\
\text { equipment* }\end{array}$ & GH $\not 500.00$ per day & $\mathrm{GH} \phi 500.00$ per day & $\mathrm{GH} \phi 500.00$ per day & $\mathrm{GH} \phi 500.00$ per day \\
\hline $\begin{array}{l}\text { Revenue per } \\
\text { week }\end{array}$ & $\begin{array}{l}\text { - } \mathrm{GH} \phi 1,400.00^{\mathrm{d}} \\
-\mathrm{GH} \phi 3,450.00^{\mathrm{e}}\end{array}$ & $\begin{array}{l}-\mathrm{GH} \phi 1,350.00^{\mathrm{d}} \\
-\mathrm{GH} \phi 3,630.00^{\mathrm{e}}\end{array}$ & $\begin{array}{l}-\mathrm{GH} \phi 1,600.00^{\mathrm{d}} \\
-\mathrm{GH} \phi 4,540.00^{\mathrm{e}}\end{array}$ & $\begin{array}{l}=\mathrm{GH} \phi 1,900.00^{\mathrm{d}} \\
-\mathrm{GH} \phi 5,420.00^{\mathrm{e}}\end{array}$ \\
\hline $\begin{array}{l}\text { Operating } \\
\text { Cost per week }\end{array}$ & $\begin{array}{l}-\mathrm{GH} \phi 1,050.00^{\mathrm{d}} \\
-\mathrm{GH} \phi 2,700.00^{\mathrm{e}}\end{array}$ & $\begin{array}{l}\text { - } \mathrm{GH} \varnothing 1,050.00^{\mathrm{d}} \\
-\mathrm{GH} \notin 3,100.00^{\mathrm{e}}\end{array}$ & $\begin{array}{l}\text { - } \mathrm{GH} \phi 1,250.00^{\mathrm{d}} \\
-\mathrm{GH} \phi 3,750.00^{\mathrm{e}}\end{array}$ & $\begin{array}{l}\text { - } \mathrm{GH} \propto 1,500.00^{\mathrm{d}} \\
-\mathrm{GH} \propto 4,600.00^{\mathrm{e}}\end{array}$ \\
\hline $\begin{array}{l}\text { Profit per } \\
\text { week }\end{array}$ & $\begin{array}{l}-\mathrm{GH} \notin 350.00^{\mathrm{d}} \\
-\mathrm{GH} \notin 750.00^{\mathrm{e}}\end{array}$ & $\begin{array}{l}\text { - } \mathrm{GH} \phi 300.00^{\mathrm{d}} \\
-\mathrm{GH} \phi 530.00^{\mathrm{e}}\end{array}$ & $\begin{array}{l}-\mathrm{GH} \varnothing 350.00^{\mathrm{d}} \\
-\mathrm{GH} \varnothing 790.00^{\mathrm{e}}\end{array}$ & $\begin{array}{l}-\mathrm{GH} \varnothing 400.00^{\mathrm{d}} \\
-\mathrm{GH} \varnothing 820.00^{\mathrm{e}}\end{array}$ \\
\hline
\end{tabular}

Source: Field Study, July 2011

Note: $G H \phi 1.51=$ US\$1.00 Exchange Rate as at July 2011

Equipment: $*=$ Excavator $* *=$ Feeding cost for a group (gang) of 6 people

${ }^{a}=$ wage for talii boys (Talii boys are mostly boys of school-going age and few men employed to carry out mining job as assigned by the operator)

${ }^{b}=$ wage for talii girls (Talii girls are mostly girls of school-going age and women employed to carry out mining jobs as assigned by the operator)

${ }^{c}=$ wage for karl men (karl men are mainly men and few women employed to carry out mining jobs such as digging, chiselling, sluicing etc the mineralized material

${ }^{d}=$ Traditional method of operating surface mining or open pit (dig \& wash)

${ }^{e}=$ Mechanized method of operating surface mining or open pit (dig \& wash)

It must be said that the structure (managerial structures), conduct (choice of technology), and performance (profitability) of small-scale mining operations in the Bibiani, Bolgatanga, Dunkwa, and Tarkwa mining districts are not the best. However, by educating the miners, especially the licensed operators, on the best mining practices and providing financial and technical support, it is possible for small-scale mines to graduate to large mines in the near future.

\section{CONCLUSIONS AND RECOMMENDATIONS}

In general, volume of production, levels of employment, and the number of licensed operators increased significantly in the four mining districts over the period under review. The Tarkwa mining district produced the highest output and contributed $54.35 \%$ of the total gold production in the four mining districts, while the Bibiani mining district produced the least (approximately 8.70\%) of total production. In terms of the number of miners employed by the licensed operators, the Bolgatanga mining district recorded the highest employment (30.56\%) of the total employment, whereas the Tarkwa district registered the least employment (18.91\%). Besides, $40.89 \%$ of the total number of licensed operators/concessions in the four mining districts was located in the Tarkwa mining district whereas the Bolgatanga district recorded the least (12.00\%). 
The results of the two-way or factor ANOVA showed that both location (mining districts) and time (years) matter much in the mining districts (Bibiani, Bolgatanga, Dunkwa, and Tarkwa) as far as production volume and the number of licensed operators/concession are concerned. However, in respect with employment levels, location of the mining district matters much, whereas time (years) does not matter.

Managerial structures, choice of technology, and profitability are among the major factors or issues that explain the magnitude of the differences in the mining districts, and the more the miners use mechanized methods in production, the more the environment is destroyed.

This paper concludes that the small-scale mining sector has contributed - and continues to contribute - to national development in terms of gold production and the employment it offers to thousands of people; therefore, it should be recognised as a significant generator of rural livelihoods that has the potential to alleviate poverty and be a tool for sustainable development. The paper suggests that efforts should be made to improve the production and employment potentials of the small-scale mining sub-sector.

This will help the small-scale mining sector contribute significantly to poverty reduction in the rural communities in Ghana. Adequate financial support must be provided to small-scale miners, which will help them improve the level of production and employment. Furthermore, technical equipment should be provided for mining and environmental regulatory institutions to ensure effective monitoring of small-scale mining in Ghana. This would also enable the institutions to build the capacity of the local communities to monitor environmental compliance.

\section{ACKNOWLEDGEMENT}

We wish to acknowledge Prof. J. Ohene-Manu (Head of Dept. of Economics, Kwame Nkrumah University of Science and Technology- Kumasi) and Prof. Ebo Mensah (Dean, Faculty of Economics and Business Administration, Catholic University College of Ghana-Fiapre) for their painstaking reviews and constructive criticism.

\section{AUTHOR INFORMATION}

George Lord Opoku-Antwi is a Lecturer of Economics at the Catholic University College of Ghana, Fiapre and Sunyani Polytechnic, Sunyani - Ghana. He obtained a Bachelor Degree in Economics and Sociology from the Kwame Nkrumah University of Science \& Technology, Kumasi - Ghana in 1991. George also holds a Master of Arts Degree in Economics from the same University in 2001. George is currently studying for his $\mathrm{PhD}$ at the Department of Economics, Kwame Nkrumah University of Science \& Technology, Kumasi - Ghana and his research interest is in mining, especially, in small-scale gold mining operations in developing countries like Ghana. Over the past twelve years, George's carrier has been focused on teaching and involvement in community service and these have helped him gain extensive knowledge and experience in University and Polytechnic education in Ghana. E-mail: glopok2006@yahoo.co.uk

Kwaku Amofah holds an MA degree in Management from the University of Wolverhampton - UK, a BA (Hons) in Economics and Sociology from the University of Cape Coast and a Certificate in Instructional Skills from the University of Vancover Island-Canada. Kwaku is currently pursuing a Doctoral programme in Management at SMC University, Switzerland. Kwaku has been a Full-time lecturer in Entrepreneurship and Marketing at the Sunyani Polytechnic since 2006. Kwaku is also a Facilitator in Strategic Management, Management and Organisation and Public Systems Management at the Kwame Nkrumah University of Science and Technology, where he has been facilitating and supervising MBA/PA students' Dissertations since 2008. Kwaku is currently the Executive Director of Brong Ahafo Research and Extension Centre (BAREC) - a collaborative partnership of three tertiary institutions. Kwaku has attended and presented at a couple of conferences. E-mail: kwakuamofah@yahoo.com. Corresponding author.

Kofi Nyamaah-koffuor was Educated at UCC (Advance Teacher Training College) and Hull University (UK). Holds an MBA in Business Administration from Hull University. Former Head of Accountancy Department, former 
Dean - School of Business \& Management Studies and currently the Head of Quality Assurance \& Control Unit, of Sunyani Polytechnic. Kofi has attended and presented at a number of conferences. E-mail: knyamaahkoffuor@rocketmail.com

\section{REFERENCES}

1. Fisher, F.M (1970). "Tests of Equality between Sets of Coefficients in Two Linear Regressions: An Explanatory Notes.” Econometrica, 38:.361 - 366.

2. Hentschel Thomas, Hruschka Felix and Priester Michael (2002). Global Report on Artisanal \& Small-Scale Mining, Minerals, Mining and Sustainable Development (MMSD), International Institute for Environment and Development (IIED) and World Business Council for Sustainable Development (WBCSD). Working Paper. (January 2002). 2-69.

3. Hill, T. (2007). Small Business Production/Operations Management, London: Macmillan Education Ltd.

4. International Labour Organisation (1999). "Labour and Social Issues in Small-scale Mines." Report for Discussion at the Tripartite Meeting on Labour and Social Issues in Small-scale Mines. Geneva: International Labour Office. (May 1999).

5. Jennings, Norman S. (1993). "Small-Scale Mining in Developing Countries: Addressing Labour and Social Issues." New York: United Nations. (February 1993). 90 - 97.

6. $\quad$ Koutsoyiannis, A (2006). Theory of Econometrics, $2^{\text {nd }}$ Ed., New York: Palgrave.

7. Minerals and Mining Act, 2006 (Act 703).

8. Minerals Commission (2007). "Mining as an Agent of Development." Retrieved from www.ghanamining.org/ghweb/en/ma/mincom.html (accessed on 2009 September 3).

9. Ngahu, C. (1992). "Choice of Technology in Small-Scale Enterprises in Kenya", International Research Development Centre (IDRC) Research Report, International Research Development Centre, Nairobi Kenya, October 1992.

10. Small-Scale Gold Mining Law 1989 (PNDCL 218).

11. World Bank (1995). Artisanal Mining Round Table: Issues for Discussion, Washington. DC. (May 1995) retrieved from www.ghanamining.org (accessed on 2007 September 23. 


\section{APPENDIX}

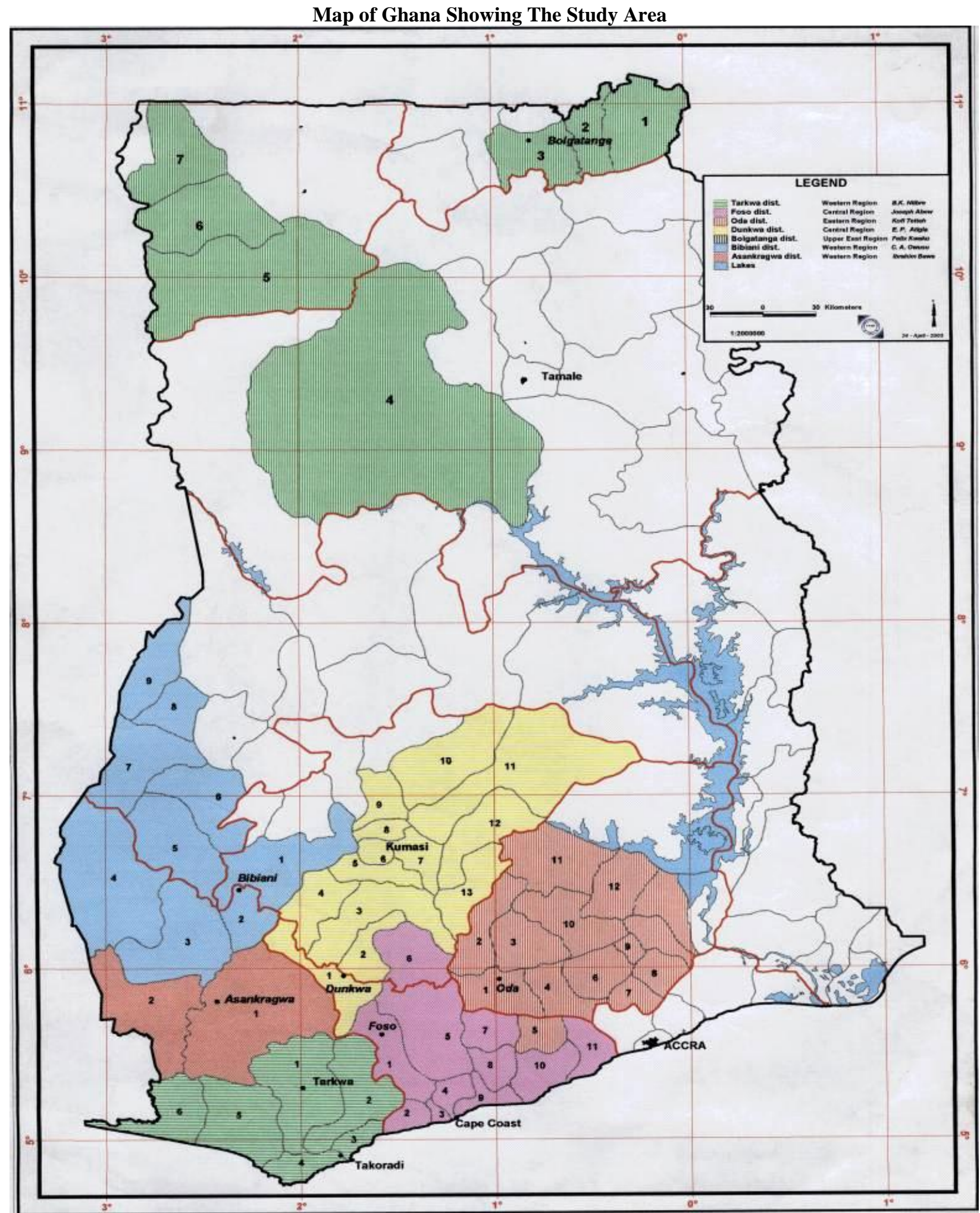

Source: Minerals Commission of Ghana 